\title{
Yılan Isırmaları ve Antivenom Tedavisinin Önemi
}

@ (1D) Prof. Dr. Ali Karakuş¹, @ (10) Öğr. Gör. Ezgi Atalay²

${ }^{1}$ Hatay Mustafa Kemal Üniversitesi Tıp Fakültesi Acil Tıp Anabilim Dalı, Hatay, Türkiye

${ }^{2}$ Bolu Abant İzzet Baysal Üniversitesi, Mehmet Tanrıkulu Sağlık Hizmetleri Yüksek Okulu, İlk ve Acil Yardım Programı, Bolu, Türkiye

$\ddot{0} z$

Yılan Isırmaları ve Antivenom Tedavisinin Önemi

Yılan venomları kompleks enzim ve toksik proteinler içerir. Hastaların kliniği kuru ısırıktan ölüme kadar çok geniş yelpazede olabilir. 13 yaşında kız çocuğu acil servise 1 saat önce yılan ısırması nedeniyle getirildi. Genel durumu kötü, şuuru konfüze, ajite ve Glasgow Koma Skalası 10 idi. Tansiyon arteryel 90/40 mmHg, nabız 120/dk idi. Sağ ayak dış malleolde hafif ödem, hematom, ekstremitelerde ekimotik alanlar ve ağız içinde kanaması mevcuttu. Kan tahlillerinde anormal olarak pansitopeni ve International Normalized Ratio (INR) yüksekliği tespit edildi. Hastaya toplam 14 ampul yılan antivenomu verildi. Üç gün boyunca takip edilen hasta şifayla taburcu edildi. Antivenom tedavisi zamanında, yeterli dozda ve uygun hastaya verilmelidir. Bu sayede oluşabilecek mortaliteler önlenebilir.

Anahtar Kelimeler: Yılan Isırması, Antivenom Tedavi, Morbidite

\section{Abstract}

\section{Snake Bites and Significance of Antivenom Treatment}

Snake venoms contains complex enzymes and toxic proteins. Snake bites have a wide clinical spectrum from dry bites to death. 13-yearold the girl child was brought to emergency service with a snake bite complaint. General medical condition was not good. Patient was agitated and confused, but able to answer question. Her Glasgow coma scale (GCS) was 10. On admission her vital signs were temperature $36.3{ }^{\circ} \mathrm{C}$, blood pressure $90 / 40 \mathrm{mmHg}$, pulse rate 120/min, and pulse oximetry reading of 94\%. Outer right lateral malleolus has slight edema, hematoma, ecchymotic areas in extremities, and hemorrhage in the mouth. Pancytopenia and elevated INR were detected. The snake antivenom was given total 14 ampoules to the patient. After 3 days of follow-up, the patient was discharged with healing. Antivenom treatment should be given at the appropriate time, in a sufficient dose and in the appropriate patient. Thus, possible deaths can be prevented.

Keywords: Snake Bites, Antivenom Treatment, Morbidity

\section{Giris}

Dünya genelinde yılda ortalama 400 bin hayvan ısırması olgusu görülmektedir. Bu olguların yaklașık 40 bini ölmektedir. Ülkemizde en sık engerek-viperidea (boz yılan) türü bulunmaktadır. Yılan venomu kompleks enzim ve toksik proteinler içerir. Hastaların kliniği kuru ısırıktan ölüme kadar çok geniş yelpazede olabilir $(1,2)$. Antivenom; şok, nörotoksik bulgular, spontan kanama ve hızla ilerleyen ödem gibi bulgu ve semptomlar varsa verilmelidir $(2,3)$.

\section{OLGU}

13 yașında kız çoçuğu acil servise 1 saat önce yılan ısırması nedeniyle getirildi. Hastanın genel durumu kötü, şuuru konfüze, ajite ve Glasgow Koma Skalası 10 (E:3 M:4 V:3) idi. Tansiyon arteryal 90/40 mmHg, nabız 120/dk idi. Sağ ayak dış malleolde kanamalı iki adet diş izi ile birlikte alt ekstremitede yaygın ödem ve ekimotik alanlar mevcuttu. Hastanın ağız içerisinde diş etlerinde kanaması mevcuttu. Diğer fizik muayene bulguları normaldi. Tespit edilen ANORMAL laboratuvar değerleri Tablo 1 de sunuldu. Karaciğer enzimleri, böbrek fonksiyon testleri, kreatin kinaz değerleri, kan gazı değerleri ve tam idrar tetkiki normaldi. Hastanın periferik yaymasında; \%80 polimorfonükleer lökosit, \%17 lenfosit, \%3 monosit, toksik granülasyon +, trombositler bol tekli nadir ikili, eritrositler hipokrom normositerdi ve hemoliz saptanmadı. 


\begin{tabular}{|c|c|c|c|c|c|c|c|}
\hline & $\begin{array}{c}\text { Beyaz küre } \\
\text { /mm3 }\end{array}$ & $\begin{array}{c}\text { Hemoglobin } \\
\mathrm{gr} / \mathrm{dl}\end{array}$ & $\begin{array}{c}\text { Hematokrit } \\
\%\end{array}$ & $\begin{array}{c}\text { Trombosit } \\
\text { /mm3 }\end{array}$ & $\begin{array}{l}\text { PT } \\
\text { sn }\end{array}$ & INR & $\begin{array}{l}\text { PIT } \\
\text { sn }\end{array}$ \\
\hline Geliș & 27,1 bin & 12,7 & 38,1 & $165 \mathrm{bin}$ & 20,9 & 1,85 & 29,4 \\
\hline 1.gün & 14,8 bin & 10,2 & 29,9 & 139 bin & 15,1 & 1,26 & 21,5 \\
\hline 2.gün & 2,25 bin & 9,68 & 28 & 41,5 bin & 15,1 & 1,26 & 21,5 \\
\hline 3.gün & 8,49 bin & 10,0 & 29,3 & 119 bin & 12,8 & 1,04 & 22,3 \\
\hline 10.gün & 10,4 bin & 12,0 & 35,8 & 127 bin & 12,2 & 0,98 & 26,5 \\
\hline
\end{tabular}

\section{Tablo 2. Ylan ısımmalarında klinik evreleme, antivenom kullanımı ve takip aşamaları (4)}

\begin{tabular}{|c|c|c|c|}
\hline Zehirlenmenin derecesi & Klinik & Antivenom kullanımı & Takip \\
\hline $\begin{array}{r}\text { Zehirlenme yok } \\
\text { EVRE } 0\end{array}$ & $\begin{array}{r}\text { Diş izi görülebilir ısırıktan sonra } \\
\text { yerel ya da sistemik zehirlenme } \\
\text { bulgusu yoktur. }\end{array}$ & Kullanılmaz. & $\begin{array}{r}8 \text { saat gözlendikten sonra taburcu } \\
\text { edilebilir. }\end{array}$ \\
\hline $\begin{array}{r}\text { Hafif zehirlenme } \\
\text { EVRE } 1\end{array}$ & $\begin{array}{r}\text { Hafif doku șisliğ̈i, hafif ekimoz, } \\
\text { sistemik bulgu yok, normal } \\
\text { laboratuar bulguları (Trombosit } \\
\text { sayısı normal), Sistolik kan } \\
\text { basıncı> } 90 \text { mmHg }\end{array}$ & Kullanılmaz & $\begin{array}{r}12 \text { saat gözlendikten sonra taburcu } \\
\text { edilebilir. }\end{array}$ \\
\hline $\begin{array}{r}\text { Orta șiddette zehirlenme } \\
\text { EVRE } 2\end{array}$ & $\begin{array}{r}\text { Artıs gösteren șişlik, o bölgede ağrı, } \\
\text { ekimoz, Prothrombin time(PT) ve } \\
\text { International Normalized Ratio } \\
\text { (INR) uzamıș, Trombosit değeri < } \\
\text { 80.000, Sistolik kan basıncı> } 90 \\
\text { mmHg }\end{array}$ & $\begin{array}{l}\text { Zehirlenmenin șiddetiyle bağlantılı } \\
\text { olarak } 2 \text { vial antivenom önerilir. }\end{array}$ & $\begin{array}{l}\text { Mutlaka monitörize edilebileceği } \\
\text { bir bölümde izlenmelidir. }\end{array}$ \\
\hline $\begin{array}{r}\text { Șiddetli zehirlenme } \\
\text { EVRE } 3\end{array}$ & $\begin{array}{r}\text { Illerleyici șişlik, o bölgede ağ } r \text {, } \\
\text { bül, nekroz gözlenir. PT uzamıș, } \\
\text { Trombosit değeri< } 80.000 \text {, Sistolik } \\
\text { kan basıncı < } 80 \text { mmHg, Ciddi } \\
\text { sistemik semptomlar, koagülopati } \\
\text { (Burun, mide vb.kanama) }\end{array}$ & $\begin{array}{r}\text { Zehirlenmenin șiddetiyle bağlantılı } \\
\text { olarak } 4 \text { vial ve üzeri antivenom } \\
\text { önerilir. }\end{array}$ & Yoğun bakımda izlenmelidir. \\
\hline
\end{tabular}

Hipotansiyonu için 20 cc/kg'dan serum fizyolojik bașlanan hastaya ajitasyonları için $0,1 \mathrm{mg} / \mathrm{kg}$ dozunda midazolam verildi. Çekilen akciğer grafisinde anormallik saptanmadı. Gelișinin 4. saatinde hastanın ajitasyonları geçti șuuru tamamen açıldı. Vital bulguları stabil hale gelen hasta acil gözlem odasına yatırıldı. Bacağı hareketsiz ve kalp seviyesinde tutmak amacı ile kısa bacak ateline alındı. Tetanoz profilaksisi ve antibiyotik tedavisi başlandı. 4 ampul yılan antivenomu (Sağlık Bakanlığı Avrupa engereği zehiri antivenomu- at immünoglobulini $100 \mathrm{mg} / \mathrm{ml}$ ) $10 \mathrm{ml}$ intravenöz yoldan 100 cc serum fizyolojik içinde yavaş kontrollü infüzyon șeklinde verildi. Hastaya toplam 14 ampul yılan antivenomu verildi. 3 gün boyunca takip edilen hasta şifayla taburcu edildi. 10. günde kan değerlerinde anormallik saptanmadı (Tablo 1).

\section{TARTIŞMA}

Yılan venomu pıhtılaşma mekanizmalarını etkileyen bazı maddeleri, proteolitik enzimleri ve nörotoksinleri içerir. Genellikle bir saat içinde ağrı, ödem, kanama, ekimoz görülür. Ödem 48-72 saat içinde yayılabilir. Zehrin cinsine göre tüm sistemler tutulabilir (2). Nörotoksik etki ile nörotoksinler presinaptik kavşakta sinir uçlarına geri dönüşümsüz olarak bağlanarak asetilkolin salınımı ve nöromusküler blokaj meydana getirir. Hemototoksik etki ile yoğun doku yıkımı ve yaygın damar içi pıhtılaşma oluşur (4). Bölgesel doku ödemi, ekimoz, hipotansiyon, şok, anksiyete, nedeni belli olmayan şuur bozukluğu, hematüri, trombositopeni, lökositoz, anemi, trombosit sayısında düşüş, INR seviyesinde yükselme, DiC (Dissemine İntravaskuler Koagulasyon) ve böbrek yetmezliği 
görülebilir. Yılan ısırığına bağlı diş izleri, ödem ve ekimoz en sık görülen bulgulardandır (5-7). Bizim olgumuzda da literatürle uyumlu olarak benzer bulgular olmakla birlikte, klinik seyir sırasında lökopeni tespit edildi.

Yılan ısırmalarının acil servisteki takip ve tedavisinde diğer acil hastalıklarda olduğu gibi öncelik; hemodinamik stabilitenin sağlanması amaçlı ABC (havayolu, solunum, dolaşım) nin değerlendirilmesi ve vital bulguların stabilizasyonudur. Havayolu açıklığı mevcut olan hastaya hidrasyon amaçlı sıvı tedavisi verilmesinin ardından lokal etkilenimin tedavisi için alt ekstremite ateli ve diğer sistemik bulguların tedavisi için antivenom tedavi bașlanmalıdır. Antivenom bulunmadığı durumlarda hematolojik etkilenimin düzeyine göre eritrosit süspansiyonu, taze donmuş plazma ve trombosit süspansiyonu diğer tedavi seçenekleridir (8). Açı yarası olan hastaya tetanoz profilaksisi ve antibiyoterapi diğer tedavilerdir.

Antivenom tedavi hastanın klinik evrelemesine göre evre 3-4 olarak kabul edilen; ekstremite ödeminde ilerleme olan, şok, nörotoksik bulgu, spontan kanama gibi bulguları olan hastalarda önerilmektedir (Tablo 2). Antivenom tedavisi sırasında \%25-75 oranında anaflaksi ve serum hastalığı gelișebilir $(9,10)$, Antivenom tedavisinin tüm yılan ısırması vakalarının tedavisinde uygulanması gereksizdir. Evreleme sonrası tedavi planlanmalıdır. Hastaya $20 \mathrm{cc} / \mathrm{kg}$ dozunda serum fizyolojik, tetanoz ve antibiyoterapi bașlandı. Pansitopeni tespit edilen, ekimozu ve ağız içi kanaması olan hastaya antivenom tedavisi başlandı. Bir saatte 250 cc izotonik içerisinde gidecek şekilde 4 flakon yılan antiserumu uygulandı. Ek kan ürününe gerek olmadan hastanın kliniği düzeldi.

\section{SONUÇ}

Hastaların acil tedavilerinin planlanmasının ardından antivenom tedavisi; zamanında, yeterli dozda ve uygun hastaya verilmelidir. Antivenom tedavisi sonrası kanama bozuklukları ve organ yetmezlikleri gibi sistemik bulgular önlenebilir.

\section{BILDIRIMLER}

Değerlendirme

Harici çift kör danışmanlık

Çıkar Çatıșması

Yazarlar bu makale ile ilgili herhangi bir çıkar çatışması

bildirmemișlerdir.

Finansal Destek

Yazarlar bu makale ile ilgili herhangi bir malî destek kullanımı bildirmemişlerdir.

\section{Etik Beyan}

Bu çalıșmada tanımlanan olgunun ailesinden gerekli izin alınarak "Aydınlatılmış onam formu" düzenlenmiş, Helsinki Bildirgesi kriterleri göz önünde bulundurulmuștur.

\section{KAYNAKLAR}

1. Karakuş A, Duru M, Kuvandık G, Kaya E, Kekeç Z. Snake Bites in Winter Season: A Case Report. Istanbul Med J. 2013;14(1):4748. https://doi.org/10.5152/imj.2013.11

2. Karakuș A, Zeren C, Celik MM, Ozden R, Arıca S, Duru M , Tasin $V$. A 5-year retrospective evaluation of snakebite cases in Hatay, Turkey. Toxicology and Industrial Health. 2015; 31(2): 188-192. https://doi.org/10.1177/0748233712472522

3. Karakuş A, Ozkan M, Karcioglu M, Ozden R, Ustun I, Calıskan K, Gokce C, Sahan M. Diabetic Foot Due to Anaphylactic Shock: A Case Report. Arch Trauma Res. 2014 ; 3(2):1-3. https://doi. org/10.5812/atr.17610

4. Kantarcı E, Kuvandik G, Hamamcı B, Karakus A. Yılan ısırması olgularının yönetimi-Management of snakebite cases - derleme- The Journal of Turkish Family Physician 2018;9(1):25-32

5. Açıkalın A. Yılan ısırmalarında düșük doz antivenom tedavinin etkinliği ve sistemik tümör nekrozis faktör- $\alpha$ salınımının mortalite ve morbidite ile olan ilișkisi. Uzmanlık Tezi. Adana, Çukurova Üniversitesi Tıp Fakültesi, 2004.

6. Karakus A. Attention to compartment syndrome in snakebites! İzmir Dr. Behçet Uz Çocuk Hast. Dergisi. 2015; 5(3):217-218. https://doi.org/10.5222/buchd.2015.217

7. Karakus A, Kuvandık G. Yılan ısırması sonrası hematüri gelișen olgu. Firat Med J. 2016; 21(4): 229-230.

8. Uçar E,Atalay E, Karakus A. Snake Bite Case Treated without Antivenom--- ARC Journal of Clinical Case Reports.2020;6(2): 26-28

9. Satar S, Karcıoğlu Ö, Sebe A. An usual localization of snakebite treated without antivenin: case report. The Mount Sınai J of Med 2005; 72:116-119 Türk Anest Rean Der Dergisi 2006; 34(5):333-336

10. Jenkins JL, Brean GR. Manuel of emergency medicine. Philadelphia. Lipincot William\& Wilkins;2000;240-45 